УДК [616-001.4-002+615.468.45]-092.9:612.275

ЭФФЕКТИВНОСТЬ КОМПЛЕКСНОГО ПРИМЕНЕНИЯ МАЗИ «ЛЕВОМЕКОЛЬ» И $10 \%$ АНТИСЕПТИЧЕСКОГО ПРЕПАРАТА «ПОВИДОН-ЙОД» В ЛЕЧЕНИИ ОСТРОГО ГНОЙНОГО ВОСПАЛЕНИЯ МЯГКИХ ТКАНЕЙ В ПЕРИОД АДАПТАЦИИ К ВЫСОКОГОРЫЮ В ЭКСПЕРИМЕНТЕ

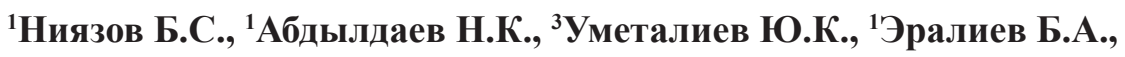

${ }^{2}$ Акматов T.А., ${ }^{1}$ Сабитов А.А.

${ }^{1}$ Кыргызский государственный медицинский институт переподготовки и повымения квалификации им. С.Б. Даниярова, Бишкек, е-таil: Nurik_02.06@mail.ru;

${ }^{2}$ Наииональный хирургический центр, Бишкек;

${ }^{3}$ Кыргызская государственная медищинская академия им. И.К. Ахунбаева, Бишкек

Изучен характер течения раневого процесса и показана оценка эффективности комплексного применения мази «Левомеколь» и 10\% препарата «повидон-йод» в лечении острого гнойного воспаления мягких тканей у экспериментальных животных, в период адаптации к высокогорью, на 3-е и 30-е сутки пребывания на перевале Туя-Ашуу (3200 м. над уровнем моря). Опыты проводились на 72 беспородных разнополых кроликах, весом 3,5-4,0 кг. Всех животных разделили на 3 группы: I группа - контрольная, опытные животные (24 особей), эксперименты проводились в условиях 770 м над уровнем моря, г. Бишкек; ІІ группа - животные с кратковременной адаптацией к высокогорью (24 особи), опыты начинали после пребывания на перевале ТуяАшуу (3200 м над уровнем моря) в течение 3 дней; III группа - опытные животные с длительной адаптацией к высокогорью (24 особи), опыты начинали после пребывание на перевале Туя-Ашуу (3200 м над уровнем моря) в течение 30 дней; Характер течения раневого процесса изучали при помощи планиметрического метода, скорость уменьшения площади ран, термометрии общего тела, бактериологических исследований, на данных лейкоцитарного индекса интоксикации. В ходе сравнения наблюдали высокую эффективность заживления ран у экспериментальных кроликов III группы, в условиях высокогорья. На 3-й день лечения площадь ран в опытной группе I составляет - 1070,5 $\pm 37,5 \mathrm{mM}^{2}(\mathrm{p} \leq 0,005)$, во II группе $-1310,0 \pm 7,07 \mathrm{mм}^{2}(\mathrm{p} \leq 0,005)$, и в III $1284,0 \pm 25,51 \mathrm{Mm}^{2}(\mathrm{p} \leq 0,005)$. На 15 - е сутки сокращение площади раны II группа отстает от других групп и составляет в среднем - 483,6 $\pm 17,78$ мм $^{2}(\mathrm{p} \leq 0,005)$, так как в І-й группе $-111,0 \pm 5,54$ мм $^{2}(\mathrm{p} \leq 0,005)$, и в III-й группе - 378,8 $\pm 35,0$ мм² $\left.^{2} \mathrm{p} \leq 0,005\right)$, показатели I, II, III-й групп на 20-е сутки составили $111,0 \pm 5,54 \mathrm{mM}^{2}$ $(\mathrm{p} \leq 0,005), 268,3 \pm 9,07$ мм $^{2}(\mathrm{p} \leq 0,005)$ и $203,6 \pm 6,18(\mathrm{p} \leq 0,005)$ мм $^{2}$, показывает, что при кратковременной адаптации к высокогорью отмечается неблагоприятное и затяжное течение заживления.

Ключевые слова: высокогорье, адаптация, раневой процесс, повидон-йод, левомеколь

\title{
EFFICACY OF COMBINED APPLICATION OF «LEVOMEKOL» OINTMENT AND $10 \%$ POVIDONE IODINE (BETADINE) ANTISEPTIC MEDICINE IN THE TREATMENT OF ACUTE SUPPURATIVE INFLAMMATION OF SOFT TISSUES DURING THE COURSE OF HIGH MOUNTAINS ADAPTATION BASED ON EXPERIMENT
}

${ }^{1}$ Niyazov B.S., ${ }^{1}$ Abdyldaev N.K., ${ }^{3}$ Umetaliev Yu.K., ${ }^{1}$ Eraliev B.A., ${ }^{2}$ Akmatov T.A., ${ }^{1}$ Sabitov A.A. ${ }^{1}$ Kyrgyz State Medical Institute of Post-graduate Training and Continuous Education named after S.B. Daniyarov, Bishkek, e-mail: Nurik_02.06@mail.ru; ${ }^{2}$ National Surgical Center, Bishkek; ${ }^{3}$ Kyrgyz State Medical Academy named after I.K. Akhunbaev, Bishkek

The nature of the course and the evaluation of the effectiveness of the complex application of «Levomekol» ointment and $10 \%$ of «povidone-iodine» antiseptic drug in the treatment of acute purulent inflammation of soft tissues in experimental rabbits during the short and long-term adaptation to the highlands, on the 3rd and 30th days of stay at Tuia-Ashuu pass (3200 m above sea level). The experiments were carried out on 72 outbred rabbits of different genders, weighing $3.5-4.0 \mathrm{~kg}$. All animals were divided into 3 groups: 1-group - experimental animals (24 samples), the experiments were carried out in conditions of $770 \mathrm{~m}$ above sea level, Bishkek; I-group animals with short-term adaptation to high mountains ( 24 samples), the experiments started after being on the Tuia-Ashuu pass (3200 m above sea level) for 3 days; Š-group - experienced animals with a long-term adaptation to the highlands (24 samples), the experiments started after a stay on the Tuia-Ashuu pass (3200 $\mathrm{m}$ above sea level) for 30 days; Studied the dynamics of the wound process was studied using a planimetric method, the rate of wound area reduction, general body thermometry, bacteriological studies, using leukocyte intoxication index data. In the course of the comparison, the high efficiency of wound healing in experimental animals of the 111-group, in conditions of high mountains, was noted. On the third day of treatment, the area of wounds in the experimental group $\mathrm{I}$ is equal to $1070.5 \pm 37.5 \mathrm{~mm}^{2}(\mathrm{p}<0.005)$, In the I-group $-1310.0 \pm 7.07 \mathrm{~mm} 2(\mathrm{p}<0.005)$. and in III $1284.0 \pm 25.51 \mathrm{~mm}^{2}(\mathrm{p}<0.005)$. On the fifteenth day the reduction of the wound area II - group lags behind other groups and averages $-483.6 \pm 17.78 \mathrm{~mm}^{2}(\mathrm{p}<0.005)$, Since in the 1 st group $-111.0 \pm 5.54 \mathrm{~mm}^{2}(\mathrm{p}<0.005)$. and in the III group $-378.8 \pm 35.0 \mathrm{~mm}^{2}(\mathrm{p}<0.005)$. indicators of the 1-, P-, U-th groups on the 20th day were $111.0 \pm 5.54 \mathrm{~mm}^{2}(\mathrm{p}<0.005), 268.3 \pm 9.07 \mathrm{~mm}^{2}(\mathrm{p}<0.005)$ and $203.6 \pm 6,18(\mathrm{p}<0.005) \mathrm{mm}^{2}$, shows that during short-term adaptation to high mountains, an unfavorable and prolonged course of healing is observed.

Keywords: high mountains, adaptation, wound process, Povidone Iodine (Betadine), Levomekol 
Несмотря на достигнутые успехи в гнойной хирургии, сохраняется актуальность раневой инфекции [1]. О нерешенности проблем в гнойной хирургии свидетельствует рост числа антибиотикоустойчивых гноеродных микроорганизмов, послеоперационных гнойных осложнений, различных видов токсико-аллергических реакций [2-3]. Все это приводит к отсутствию универсального средства и метода лечения ран и сложностью выбора универсальной тактики ведения и метода лечения гнойных ран в период адаптации к изменяющимся факторам внешней среды [4].

В высокогорных условиях при миграции у большинства людей развиваются адаптационные расстройства, которые ведут к отягощенности многих хронических заболеваний, которые были изучены многими нашими отечественными учеными в конце прошлого столетия [5-6]. Их работами было установлено, что в горах организм человека начинает функционировать на качественно и количественно новом физиологическом уровне. Этот новый адаптационный патофизиологический уровень организма в горах влияет на течение, лечение и исход заболеваний, том числе и на лечение гнойных ран.

Адаптация организма к условиям высокогорья сопровождается изменениями со стороны «красной» крови и свертывающей системы. В различных горных районах характер изменений красной крови неодинаков, он зависит от высоты горных местностей, тренированности организма и от начального показателя организма перед подъемом в горы [7-8]. В условиях низкогорья нейтрофилия развивается усиленной работой костного мозга или увеличением их количества в крови человека. Известно, что длительная нейтрофилия сохраняется при наличии инфекции в организме, на фоне стрессового состояния организма [9]. В условиях высокогорья инфекция отходит на второстепенное значение. На нейтрофилию в организме, в условиях высокогорья, влияет больше всего стресс. Когда организм адаптируется к экстремальным условиям высокогорья через длительный период, в организме происходит иммунологическая перестройка с увеличением числа лимфоцитов [10-11]. Согласно данным отечественных исследователей, на 3-е сутки пребывания в условиях высокогорья, происходит уменьшение количества лимфоцитов периферической крови, после 15-дневного пребывания количество антигена оставалось высоким. Таким образом, исследователями показано, что в остром периоде адаптации снижается функциональная активность нейтрофилов и моноцитов, что говорит о целесообразности иммунокорегирующей терапии при подъеме в горы [12]. Исследователи в эксперименте на кроликах, на модели асептического воспаления, показали, что в условиях высокогорья у животных местное воспаление слабо выражено, это связано с запаздыванием воспалительной реакции, снижением переваривания и индекса переваривания фагоцитов и нейтрофилов. По данным авторов, до трех недель не происходит окончательного формирования воспалительного процесса - в форме лихорадочной и лейкоцитарной реакции [13].

В доступной нам литературе исследований, посвященных изучению характера течения раневого процесса в период адаптации к условиям высокогорья, мало.

Цель исследования: показать характер течения раневого процесса и эффективность комплексного применения мази «Левомеколь» и $10 \%$ антисептического препарата «Повидон-йод» в лечении острого гнойного воспаления мягких тканей в период адаптации к условиям высокогорья в эксперименте.

\section{Материалы и методы исследования}

Исследование провели на 72 беспородных кроликах. Основные правила ухода, содержания и дизайн исследования проведены в соответствии с Европейской конвенцией о защите позвоночных животных, используемых для экспериментов или в иных научных целях (European Convention for the Protection of Vertebrate Animalsused for Experimental and Other Scientific Purposes, 18.03.1986) и согласованы с этическим комитетом при Министерстве здравоохранения Кыргызской Республики.

Экспериментальных животных разделили на 3 группы по 24. I - опытная группа, 24 кролика, находящихся в условиях низкогорья (г. Бишкек 770 м над уровнем моря); II - опытная группа, 24 кролика, после кратковременной, 3-х дневной адаптации к высокогорью на высоте 3200 м над уровнем моря; III - экспериментальная группа, 24 кролика, после длительной, 30-дневной адаптации в горах, на высоте 3200 м над уровнем моря.

Острое гнойное воспаление мягких тканей у экспериментальных животных вызывали по методике «Моделирование стандартной обширной гнойной раны мягких тканей кожно-лоскутным методом» (Рационализаторское предложение № 832 от 19 мая 2016 г. Национального хирургического центра им. М.М. Мамакеева при Министерстве здравоохранения Кыргызской Республики). Оценка состояния гнойной раны проводилась на 3-, 7-, 15- и 20-е сутки раневого процесса. Контроль за течением раневого процесса, в эксперименте, осуществлялась на основании планиметрического метода, скорость уменьшения площади ран, термометрии общего тела, бактериологических исследованийи на данных лейкоцитарного индекса интоксикации. 
Площадь раны и процент уменьшения площади опредяляли планиметрическим методом исследования Л.Н. Поповой.

$$
(\mathrm{S}-\mathrm{Sn}) \mathrm{x} 100 / \mathrm{SxT} \text {, }
$$

где $\mathrm{S}$ - величина площади ран $\left(\mathrm{Mm}^{2}\right), \mathrm{Sn}$ - величина площади ран $\left(\mathrm{Mм}^{2}\right), \mathrm{T}$ - число дней между измерениями.

Лейкочитарный индекс интоксикаиии (ЛИИ) вычислялся на основании полученных данных при общем анализе крови, по формуле Я.Я. Кальф-Калифа (1941):

$$
\frac{(4 \mathrm{Mц}+3 Ю+2 П+\mathrm{C})(\text { Пл }+1)}{(\text { лим }+ \text { мон })(Э+1)}=\text { ЛИИ, }
$$

где Мц - миелоциты, Ю - юные, П - палочкоядерные, C - сегментоядерные, Пл - плазматические клетки Тюрка, Лим - лимфоциты, Э - эозинофилы, Мон моноциты. В норме - 0,5-1,5 единиц.

\section{Термометрия области рань и общего тела}

Термометрию раневой поверхности и интактного участка кожи выполняли с помощью цифрового термометра для животных. Термометрию общего тела проводили путем введения в анальное отверстие кролику на глубину не более 2,0 см, после смазывания кончика термометра вазелином.

Для бактериологического исследования материал брали из глубины раны стерильным ватным тампоном и помещали в стерильную пробирку. Посев материала осуществляли на простой агар, желчно-солевой агар.

Статистическая обработка проводилась с помощью пакета компьютерной программы SPSS 23.0. Нормальность распределения количественных признаков проверяли с использованием критерия Колмогорова - Смирнова, равенство дисперсий с критерием Levene. Для сравнения результатов в различных группах проводили методами параметрической (ANOVA) и непараметрической статистики (критерий Краскеля-Уоллеса), Критерий Тьюки выбран апостериорным критерием. Критическое значение уровня значимости считалось $\mathrm{p}<0,05$.

\section{Результаты исследования и их обсуждение}

При планиметрическом исследовании площади ран средняя площадь всех экспериментальных ран на момент начала исследования составила 2011,6 $\pm 1,47$ мм² $^{2}$ На 3-е сутки лечения выявлено, что разница между I и II группой не больше чем с III группой, но разницы не большие. Начиная с 7-х суток можно говорить о формировавшихся различиях между группами, которые составляют, в I группе - 1070,5 $\pm 37,5$ мм $^{2}$, во II группе $1310,0 \pm 7,07 \mathrm{Mм}^{2}$ и в III $-1284,0 \pm 25,51 \mathrm{мм}^{2}$ (рис. 1).

На 15-е сутки сокращение площади раны II группа отстает от других групп и составляет в среднем $-483,6 \pm 17,78$ мм² $^{2}$, так

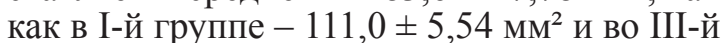

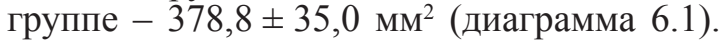
Так исследуемые показатели I, II, III-й групп

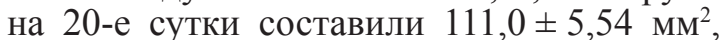
$268,3 \pm 9,07 \mathrm{Mм}^{2}$ и 203,6 $\pm 6,18$ мм² $^{2}$ что еще раз показывает, что влияние высокогорного климата и влияние кратковременной и длительной адаптации значительно влияет на пролиферативные процессы и на ускорение регенерации раны.

Данные ЛИИ. Ликвидация воспалительного процесса в данных группах показывает, что при кратковременной адаптации ликвидация воспалительного процесса идет очень медленно. Во II и III-й группе отмечалась гипоэргическая реакция на внедрение инфекции, и поэтому воспалительный процесс протекал вяло и длительно (рис. 2).

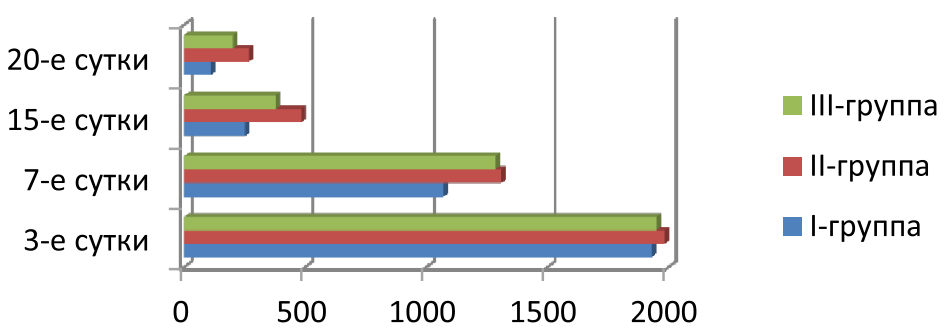

Рис. 1. Динамика изменения площади ран (мм²) при заживлении экспериментальной гнойной раны $(M \pm s)$. Примечания: $p<0,5$

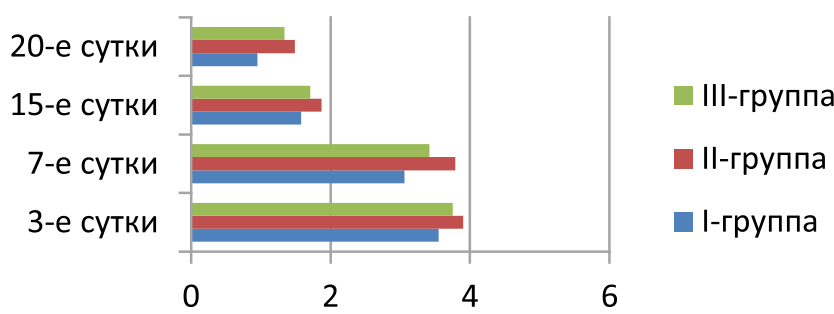

Рис. 2. Показатели ЛИИ у экспериментальных животных за период наблюдения. Примечания: $p<0,5$ 
Температура поверхности раны $\left(\right.$ в $\left.{ }^{\circ} \mathrm{C}\right)$

\begin{tabular}{|c|c|c|c|c|}
\hline & 3-день & 7 день & 15 день & 20 день \\
\hline Здоровые кролики Интактная кожа & $38,2 \pm 1,2$ & $38,4 \pm 0,4$ & $38,2 \pm 1,3$ & $38,3 \pm 0,2$ \\
\hline Просто рана (M1 \pm s1) & $40,7 \pm 0,16$ & $40,8 \pm 0,42$ & $39,8 \pm 0,10$ & $39,4 \pm 0,08$ \\
\hline Левомеколь (M2 \pm s2) & $40,4 \pm 0,18$ & $40,2 \pm 0,14$ & $39,2 \pm 0,10$ & $39,5 \pm 0,13$ \\
\hline Повидон-йод (M3 \pm s3) & $40,0 \pm 0,16$ & $40,1 \pm 0,19$ & $39,4 \pm 0,19$ & $39,2 \pm 0,16$ \\
\hline Левомеколь + Повидон-йод (M4 \pm s4) & $39,5 \pm 0,13^{1{ }^{1 *}}$ & $39,6 \pm 0,14^{1 " *}$ & $38,7 \pm 0,20^{11 *}$ & $38,7 \pm 0,13^{1 " *}$ \\
\hline
\end{tabular}

П р и м е ч а н и : * - p $<0,5$ (показатель различия M1-M4); $-\mathrm{p}<0,5$ (показатель различия между M2-M4); ${ }^{1} \mathrm{p}<0,5$ (показатель различия M3-M4).

Микробиологическая характеристика гнойных ран

Таблица 2

\begin{tabular}{|l|c|c|c|}
\hline \multicolumn{1}{|c|}{ Виды микрофлоры раны } & I группа & II группа & III группа \\
\hline Staphylococcus aureus, $\%$ & 81,25 & 81,25 & 68,75 \\
\hline Pseudomonos aeruginosae, $\%$ & 25,0 & 0 & 0 \\
\hline Proteus mirabilis, \% & 18,75 & 6,25 & 0 \\
\hline Esherichia coli, $\%$ & 6,25 & 6,25 & 0 \\
\hline Staphylococcus haemoliticus, $\%$ & 6,25 & 6,25 & 0 \\
\hline Proteus vulgaris, \% & 0 & 0 & 6,25 \\
\hline
\end{tabular}

Данные термометрии в период длительной адаптации к высокогорью показывают состояние анаэргии организма, как и у кроликов в период кратковременной адаптации. Об уменьшении воспалительной реакции при комплексном применении мази «Левомеколь» и $10 \%$ препарата «Повидон-йод» свидетельствовали все показатели (табл. 1).

Анализ бактериальной обсемененности I, II, III групп показало, что в I и III-й группе в ране развивается одинаковая по виду микрофлора. В то же время наблюдается, что в III-й группе по процентным соотношениям микроорганизмов меньше по сравнению с I-й группой. Во II-й группе высеяны только Staphylococcus aureus и Staphylococcus heamaliticus (табл. 2).

Результаты проведенных нами экспериментальных исследований в условиях низкогорья г. Бишкек 760 м над. ур. моря, высокогорья на перевале Туя-Ашуу (3200 м н.ур. моря) в период кратковременной и длительной адаптации к высокогорью показали, эффективность комплексного применения мази «Левомеколь» и $10 \%$ антисептического препарата «Повидон-йод» при лечении гнойных ран в сравнении с традиционным методом лечения:

1. Сравнительная оценка уменьшения площади экспериментальной гнойной раны при применении мази «Левомеколь» и $10 \%$ препарата «Повидон-йод» имеет положительный и достоверный эффект.

2. Бактериальная обсемененность раны штаммами при адаптации организма к условиям высокогорья значительно уменьшается.

3. Исследование указывает на значение кратковременной и длительной адаптации организма к условиям высокогорья.

\section{Список литературы}

1. Луцевич О.Э. Современный взгляд на патофизиологию и лечение гнойных ран // Хирургия. Журнал им. Н.И. Пирогова. 2011. № 5. С. 72-77.

2. Горин В.С. Принципы диагностики и терапии гнойных воспалительных заболеваний придатков матки // Российский вестник акушера-гинеколога. 2008. Т. 8. № 5. C. 30-37.

3. Сыдыгалиев К.С. Анаэробная неклостридиальная флегмона верхней конечности и правой боковой поверхности груди и живота (клиническое наблюдение) // Вестник КГМА им. И.К. Ахунбаева. 2017. № 1. С. 160-160.

4. Кундашев У.К. Возможности фармокологической коррекции адаптивных реакций организма человека при краткосрочных перемещениях из среднегорья и высокогорье // Экспериментальная и клиническая фармакология. 2014. T. 77. № 9. С. 32-37.

5. Айдаралиев А.А. Оценка и прогноз функционального состояния организма человека в экстремальных условиях среды // Современные аспекты адаптации организма к экстремальным условиям. Бишкек, 1998. С. 39.

6. Данияров С.Б. Системная и органная гемодинамика в процессе адаптации к высокогорью // Современные аспек- 
ты адаптации организма к экстремальным условиям. Бишкек, 1998. С. 109

7. Агаджанин Н.А. Организм и газовая среда обитания. М.: Наука, 1972. 125 с.

8. Плотников Ф.В. Комплексное лечение пациентов с гнойными ранами в зависимости от способности микроорганизмов-возбудителей формировать биопленку // Новости хирургии. 2014. Т. 22. № 5. С. 575-581.

9. Блатун Л.А. Местное медикаментозное лечение ран // Хирургия. 2011. № 4. С. 51-59.

10. Мираков Р.С., Мираков Х.М., Мухамедова С.Г. Особенности изменения электролитного баланса у собак с единственной резецированной почкой при реадаптации к высо- когорью // Доклады Академии наук Республики Таджикстан. 2013. Т. 66. № 1. С. $82-87$.

11. Корнеева А.В. Изменение поведенческой активности у крыс с ишемией мозга, осложненной сахарным диабетом в условиях реадаптации // Вестник КРСУ. 2013. Т. 13. № 6. C. $148-150$.

12. Махмудова Ж.А. Течение катехоламинового некроза миокарда на фоне комбинированного применения атенолола и коэнзима Q10 при кратковременном пребывании животных в условиях высокогорья// Вестник КГМА им. И.К. Ахунбаева. 2014. № 1. С. 71-75.

13. Фрейдлин И.С. Современные представления о фагоцитарной теории // Журнал микробиологии, эпидемиологии и иммунобиологии. 2008. № 5. С. 4-10. 